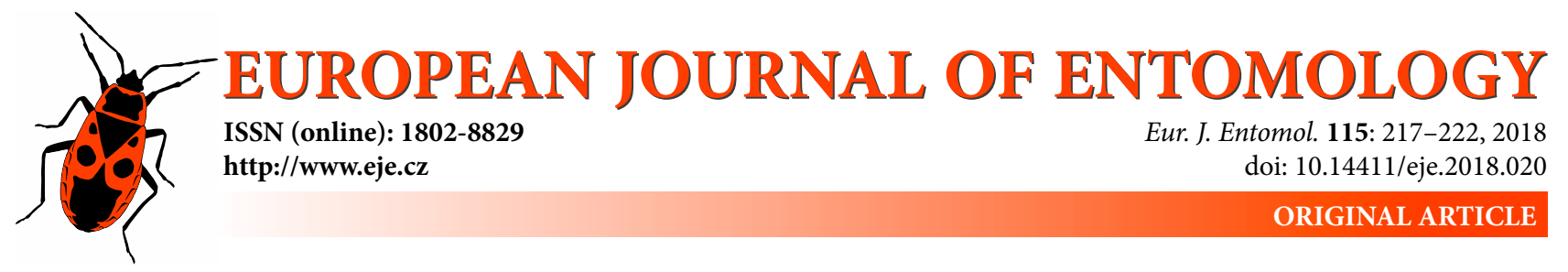

\title{
Bait visitation by Formica lemani (Hymenoptera: Fomicidae) indicates shortage of carbohydrates in alpine grasslands
}

\author{
ELIA GUARIENTO ${ }^{1}$, JAN MARTINI² and KONRAD FIEDLER ${ }^{1}$ \\ ${ }^{1}$ Dept. of Botany \& Biodiversity Research, University of Vienna, Rennweg 14, A-1030 Vienna, Austria; \\ e-mail: guariento.elia@gmail.com \\ ${ }^{2}$ Dept. of Limnology \& Bio-Oceanography, University of Vienna, Althanstraße 14, A-1090 Vienna, Austria; \\ e-mails: elvanjan@gmail.com, konrad.fiedler@univie.ac.at
}

Key words. Hymenoptera, Formicidae, Formica, ants, nutritional ecology, baits, nutrient limitation, alpine ecology, trophic position

\begin{abstract}
Insights can be gained by analysing the feeding decisions of animals in terms of nutrient demands at a species or community level. Using carbohydrate and protein food baits, resource use and food preferences of Formica (Serviformica) lemani were determined at nine locations situated at different altitudes (1875 to $2400 \mathrm{~m}$ a.s.I.) in the alpine grassland belt above the tree line in Austria and northern Italy. F. lemani is the most common species of ant in this habitat. Sucrose baits placed around ant colonies were visited by significantly (3.9 times) more workers than protein baits. This indicates that sources of sugar (carbohydrate) are in short supply in the alpine zone, whereas availability of prey items appears to be less constraining. Overall, we recorded a decrease in the incidence of visits to baits from low (31.9\% baits attracting ants at least once) to high altitudes (16.7\%). Foraging ants never visited $51.5 \%$ of the baits exposed for periods of $75 \mathrm{~min}$. This indicates that with increasing altitude competition for food among ant colonies becomes less intense in alpine grassland ant communities.
\end{abstract}

\section{INTRODUCTION}

Organisms in stressful environments are often more strongly limited by abiotic than biotic interactions (Dunn et al., 2010; Machac et al., 2011; Reymond et al., 2013; Szewczyk \& McCain, 2016). Along altitudinal gradients in high mountain areas, for most organisms, the abiotic conditions become ever more harsh and constraining with increasing altitude (Dillon, 2006; Nagy \& Grabherr, 2009). This is reflected in the well-known altitudinal zonation of vegetation in mountain chains (such as the Alps: Grabherr et al., 2003).

Ants are widely regarded as important players because of their essential role in almost all terrestrial ecosystems (Hölldobler \& Wilson, 1990; Lach et al., 2010). In alpine habitats, however, ants are far less diverse and abundant than at low altitudes in Europe. For example, of the 134 species of ants known to occur in Austria (Wagner, 2014), fewer than 20 non-parasitic species regularly occur in alpine grassland habitats above the tree line or much above $2000 \mathrm{~m}$ (Seifert, 2007). Hence, one might expect that competition among ant species and colonies becomes less intense at high altitudes, whereas more densely packed, species-rich ant communities at low altitudes are typically shaped by severe intra- as well as interspecific competition for nesting space and food resources (Machac et al., 2011).
Alpine ants are surprisingly poorly studied (Glaser, 2006; Spotti et al., 2015). In fact, apart from some regional faunal treatments and faunistic reports (e.g Cherix \& Higashi, 1979; Glaser, 2006; Seifert, 2007; Wagner, 2014), there are only a few recent papers (Reymond et al., 2013; Spotti et al., 2015) that give a deeper insight into the community composition, feeding behaviour, community constraints and concomitant changes in alpine ant assemblages with altitude. Accordingly, even though it appears to be generally accepted by ant ecologist that ant nest density decreases with increasing altitude in the Alps, we were unable to find any study that corroborates this hypothesis (but see Seifert, 2017). Even less is known about ants in the alpine grassland belt above the tree line, an area with harsh environmental conditions. For many species of ants, therefore, the tree line is the upper limit of their altitudinal distribution (Dethier \& Cherix, 1982; Machac et al., 2011).

Most species of ants in Europe and all those known to occur in the alpine zone are omnivores that feed on a mixed diet (Seifert, 2007). However, the relative contribution of predation (or scavenging) as opposed to the collection of sugary liquids (carbohydrates) may vary greatly between and within species of ants, as is indicated by stable isotope analysis (Blüthgen et al., 2003; Fiedler et al., 2007). The nutritional ecology of ants has recently attracted more at- 
tention, for example, as a means of disentangling the role of ants within an environment (Blüthgen \& Fiedler, 2004; Peters et al., 2014; Tiede et al., 2017) and address specific ecological questions (Kay, 2004; Kaspari et al., 2012). One commonly used method for assessing the feeding habits of ants is baiting (Bestelmeyer et al., 2000). By analysing the acceptance and monopolization of different types of baits it is possible to obtain information on competition, trophic position and limiting nutrients (Kaspari \& Yanoviak, 2001; Kaspari et al., 2012). Compensation theory predicts that ants should prefer those resource that are in short supply and thus in greatest demand in their environment (Kaspari \& Yanoviak, 2001). While most studies using standard baiting protocols were done in the tropics and temperate regions (e.g. Bestelmeyer et al., 2000; Kaspari et al., 2012; Fowler et al., 2014; Véle \& Modlinger, 2016), there is a lack of such studies along mountain slopes or in alpine areas (but see Peters et al., 2014; Spotti et al., 2015; Orivel et al., 2018). The only study we were able to find that explores feeding preferences of ants in an alpine setting is that of Spotti et al. (2015), with just one site located in an alpine environment above the tree line. In the present study, we used a reduced version of the baiting protocol with only protein and carbohydrate baits (e.g. Kay, 2004; Kaspari et al., 2012; Véle \& Modlinger, 2016) being offered specifically to the most abundant species of ant, Formica lemani (Bondroit, 1917), at two altitudes in the alpine grassland zone above the tree line. F. lemani is the most common species of ant in the alpine region (Dethier \& Cherix, 1982; Schiestl \& Glaser, 2012; Wagner, 2014) and has an omnivore feeding strategy that enables it to exploit new resources very fast (Schiestl \& Glaser, 2012).

By studying alpine grassland at two altitudes it is possible to compare a more productive environment (lower alpine zone) with a less productive and climatically even more stressful one (upper alpine zone), determined by the increase in abiotic constraints with altitude, but in which the structure of the vegetation is very similar (Nagy \& Grabherr, 2009). Such a contrast is ecologically even more interesting when it occurs within a very small range, such as over a small increase in altitude in the alpine environment. The alpine environment is characterized as the area that extends from the treeline to where the ground is permanently covered by snow (Nagy \& Grabherr, 2009). Since the sites higher up in the grassland zone are situated closer to the altitudinal limit of the focal ant species, one might expect constraints on nutrient availability and foraging activity to act even more strongly there.

Kaspari et al. (2000) report a reduction in ant nest density with decreasing primary production at sites in South, Central and North America. If ant density above the tree line further decreases in a similar fashion with decrease in primary production, one might expect the visits by ants to baits to decrease correspondingly.

Further, a change in abiotic severity might influence macro-nutrient availability like the abundance of prey organism (proteins) (Hodkinson, 2005) and or nectar (carbo- hydrates) produced by other insects in trophobiotic mutualisms with ants (Pellissier et al., 2012).

We here test the following predictions: (1) there are fewer visits to baits by F. lemani in the upper alpine belt because at that altitude there are stronger abiotic constraints on foraging; and (2) this ant prefers high-quality protein sources over carbohydrates in an alpine environment, since given the short growing season the chances of obtaining sufficient protein are very limited.

\section{MATERIAL AND METHODS}

Data were collected in July 2015 in the central and southern Alps. Four pairs of sites were selected as sampling areas, located along a north-to-south transect through the eastern Alps (Fig. 1). At each location, the lower site was situated in the lower alpine belt just above the tree line, and the upper site in the middle or higher alpine belt, close to the ant's upper altitudinal limit. On average, the upper and the lower sites were separated by difference in altitude of $120 \mathrm{~m}$ (total altitudinal range of upper sites: 2055$2400 \mathrm{~m}$; and lower sites: 1875-2330 m; Table 1). The lowest sites were situated in the Southern Alps (1875 m a.s.1.) and the highest in the Central Alps (2400 m a.s.1.), which mirrors the differences in the altitudinal zonation of the vegetation (and treeline) in the Central and Southern Alps (Grabherr et al., 2003).

Tea-spoon quantities of commercially available wet cat food (Whiskas ${ }^{\mathrm{TM}}$ ) were used as the protein bait (cf. Wetterer et al., 1999; Tschinkel, 2002; Stuble et al., 2013 for other studies employing similar baits). We used cat food because of its high protein content. It also contains minor amounts of carbohydrates, lipids and other compounds that we considered negligible for our experiment. Sugar-water (240 g sucrose dissolved in $1 \mathrm{~L}$ water, presented on pieces of soaked paper towel) served as the carbohydrate bait. Baits in ad libitum supply were exposed on white $4 \times 4$ $\mathrm{cm}$ square plastic frames (Bestelmeyer et al., 2000). All F. lemani ants visiting the plates were recorded every $5 \mathrm{~min}$ over a period of $75 \mathrm{~min}$ (i.e. 15 times in each observational sequence; at the first location, lower site, only 7 intervals of 10 min were sampled).

We started sampling at a site only if the weather conditions were favourable for ant foraging (sunny and between $1000 \mathrm{~h}$ and $1600 \mathrm{~h}$ ) and at least five ant nests of $F$. lemani could be easily found within an area of ca $20 \mathrm{~m}$ radius during a preliminary exploration (about $15 \mathrm{~min}$ ). Ant nests were considered as units for the analyses (i.e. we did not check whether these belonged

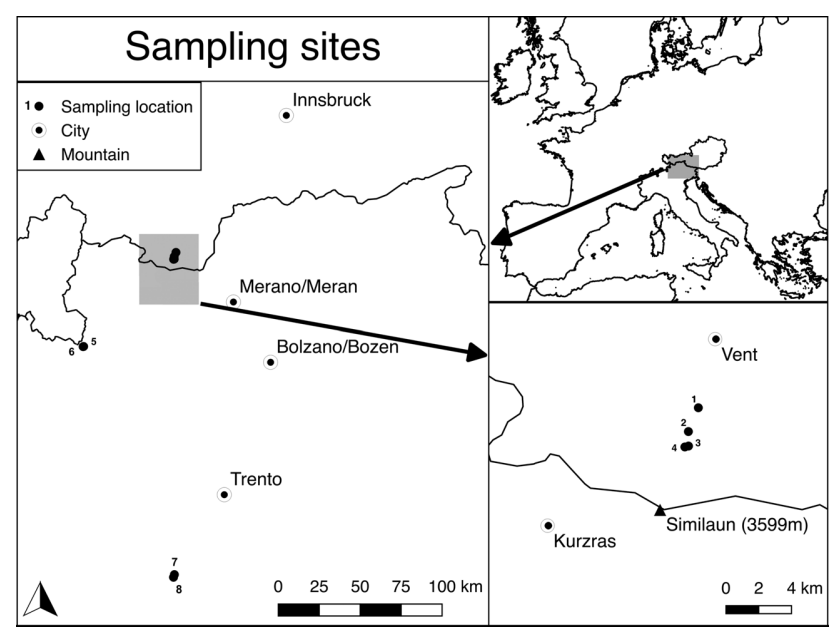

Fig. 1. Map showing the location of the sites sampled in the eastern Alps. 
Table 1. Locations, date and time of day sampled, plus the altitude and main features of the sites including major characteristics of the vegetation.

\begin{tabular}{|c|c|c|c|c|c|c|}
\hline ID & Location & Position & Date & Time & $\begin{array}{l}\text { Altitude } \\
\text { m a.s.I. }\end{array}$ & Plant community and other site features \\
\hline 1 & Martin Busch Hütte 1 & upper alpine & 3.vii.2016 & $15: 00$ & 2280 & $\begin{array}{l}\text { Alpine meadow interspersed with many stones, } \\
\text { steeply south facing slope }\end{array}$ \\
\hline 2 & Martin Busch Hütte 2 & lower alpine & 3.vii.2016 & $12: 05$ & 2134 & $\begin{array}{c}\text { Alpine meadow with dwarf shrubs (Juniperus communis, } \\
\text { Rhododendron ferrugineum) and Pinus mugo }\end{array}$ \\
\hline 3 & Morain wall 1 & upper alpine & 4.vii.2016 & 09:45 & 2400 & $\begin{array}{c}\text { Alpine meadow interspersed with many stones, } \\
\text { on east facing glacier morain }\end{array}$ \\
\hline 4 & Morain wall 2 & lower alpine & 4.vii.2016 & $12: 03$ & 2330 & $\begin{array}{l}\text { Alpine meadow interspersed with many stones, rather flat, } \\
\text { near creek running off a glacier, few dwarf Salix shrubs }\end{array}$ \\
\hline 5 & Ortler 1 & upper alpine & 7.vii.2016 & 11:05 & 2300 & Alpine meadow, lots of Dryas octopetala and Leontopodium nivale \\
\hline 6 & Ortler 2 & lower alpine & 7.vii.2016 & 13:03 & 2220 & $\begin{array}{l}\text { Alpine meadow with dwarf shrubs (Rhododendron) } \\
\text { and interspersed saplings (Larix decidua and Picea abies) }\end{array}$ \\
\hline 7 & Mt. Baldo 1 & upper alpine & 9.vii.2016 & $12: 27$ & 2055 & Alpine meadow, grass dominated, grazed by sheep \\
\hline 8 & Mt. Baldo 2 & lower alpine & 9.vii.2016 & 15:04 & 1875 & Alpine meadow with few shrubs \\
\hline
\end{tabular}

to the same polydomous colony network). This concentration on focal nests allowed a rapid assessment of the foraging behaviour of ants despite low colony density and rapidly changing weather conditions at high altitudes (Kaspari et al., 2000).

At each site, baits were exposed around five focal nests of $F$. lemani (12 baits per nest, 6 baits per resource type). Protein and carbohydrate baits were offered in alternating circular positions around each nest. The distance between the baits and the nest varied between $10-30 \mathrm{~cm}$ depending on the terrain.

First, we counted the baits that were visited at least once over the whole sampling period. This score was used as a measure of resource use, i.e. the number of worker ants attending a bait did not matter. To further consider the number of visits we summed the number of worker ants counted per bait over the total observation period. High numbers indicate a more lasting attraction of ants to a resource, including the possible onset of mass recruitment and monopolization. This score was square root transformed prior to statistical analysis to improve fit to normality assumptions.

We used the package lme4 (Bates et al., 2015) in the R environment (R Core Team, 2017) to carry out generalized linear mixed model (GLMM for ant incidence, with binomial error structure) and linear mixed-model (LMM, for ant numbers, with Gaussian

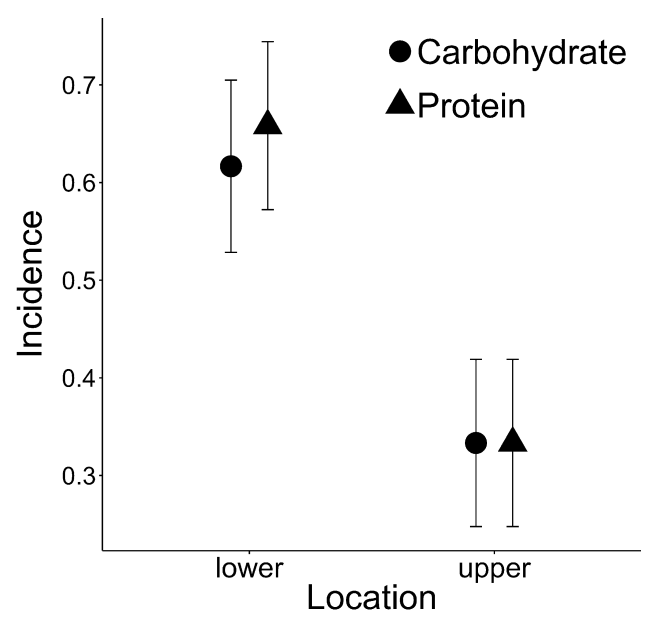

Fig. 2. The mean incidence of visits by ants (with $95 \%$ confidence intervals) revealed a clear difference in the incidence recorded in the upper and lower locations in alpine grassland, but no preference for either the carbohydrate or protein bait. error structure) analyses. As fixed factors, we used the bait type and altitudinal zone. Location ID (containing always an upper and a lower site), nest ID nested within location, as well as absolute altitude (in $\mathrm{m}$ a.s.1.) were used as random factors. Use of location as a random factor enables a comparison of the upper and lower sites. Inclusion of nest ID as a random factor makes it possible to control for differences between ant colonies in overall activity and worker population size. Altitude as a random factor enabled us to single out local climatic characteristics that we could not measure directly.

The distribution of residuals was visually inspected and was acceptable for both models. A likelihood ratio test was used to determine the importance of each fixed factor. Explained variance, viz. marginal and conditional $\mathrm{R}^{2}$, was computed using the package MuMIn (Barton, 2013). Statistical graphs were created in the environment $R$ ( $R$ Core Team, 2017) with the package ggplot2 (Wickham, 2009), showing means of the response variables and their $95 \%$ confidence intervals.

\section{RESULTS}

In total 480 baits were exposed, of which 233 (48.54\%) were visited by $F$. lemani ants at least once during the observation period. Other species of ants that visited the baits (not considered in the results and recorded at only 18 different baits, 3.3\%) included Formica lugubris ( 8 baits at the lower and 1 bait at the upper sites), Manica rubida (7 baits at the higher sites) and Myrmica sulcinodis (4 baits at the upper sites, on one simultaneously with Manica rubida). We did not observe any aggression between ant species at baits, but shared bait usage by Formica lemani and another species was observed 3 times.

Incidence of visiting baits was higher at the lower sites, $153(65.66 \%)$ counts compared to the upper sites with just

Table 2. Results of the Generalised Linear Mixed Model of the incidence of visits by ants to different baits $(\mathrm{n}=480) \cdot R_{\text {marginal/conditional }}^{2}=$ $0.148 / 0.523$. Given are figures for the fixed factors only.

\begin{tabular}{lrcrr}
\hline Fixed effects & Estimate & SE & \multicolumn{1}{c}{$z$} & \multicolumn{1}{c}{$p$} \\
\hline Intercept & -0.0614 & 0.6245 & -0.098 & 0.922 \\
Resource type & -0.0612 & 0.1128 & -0.542 & 0.588 \\
Location (upper/lower) & -1.0067 & 0.2236 & -4.503 & $<0.001$ \\
Resource type $\times$ Location & 0.0612 & 0.1128 & 0.542 & 0.588 \\
\hline
\end{tabular}




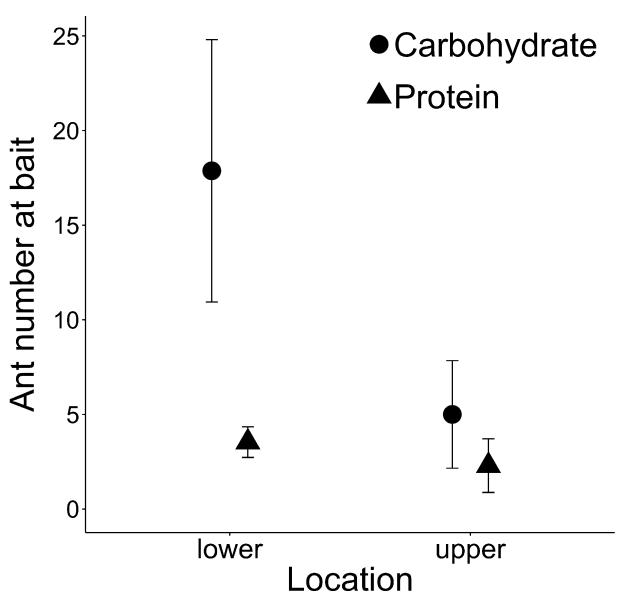

Fig. 3. The number of ants recorded at carbohydrate and protein baits (with $95 \%$ confidence intervals). At the lower alpine sites, mean number of ant visitors was almost twice as high as in the upper alpine grassland belt. Carbohydrate baits were preferred over protein baits.

80 (34.33\%) baits visited. When only the incidence of visits was taken in account there were no difference recorded for the two types of resource (Fig. 2). Only location as a fixed factor contributed significantly (Likelihood ratio test, $p=0.006$ ) to accounting for the difference in the incidence of visits (Table 2). No interaction between location and resource type was detected. Overall, resource and altitude accounted for only a minor fraction of the variance (14.84\%) in the data as shown by the low marginal $\mathrm{R}^{2}$ value.

Altogether, we recorded 3444 single sightings of worker ants of $F$. lemani at baits. In the linear mixed model the number of worker ants on baits of both types (Likelihood ratio test: $p<0.001)$ and location $(p=0.002)$ were significant terms in the model (Table 3). Carbohydrate baits (2747 workers, $79.07 \%$ ) were visited by far more ants than protein baits (699 workers, $20.29 \%$ ) and there were more visits recorded at the lower sites ( 2569 workers, $74.59 \%$ ) than the upper sites ( 875 workers, $25.41 \%$; Fig. 3 ). The preference for sucrose was far stronger at sites in the lower than in the higher alpine grassland zone.

\section{DISCUSSION}

The major outcome of our experiment is that $F$. lemani consistently prefers carbohydrate over protein baits in an alpine environment, at different altitudes and most sites sampled.

Furthermore, our experiments revealed that even when placed close to F. lemani colonies, the majority of the baits were either not or only intermittently visited by foraging

Table 3. Results of the Linear Mixed Model of the number of ants recorded at baits ( $\mathrm{n}=480$ baits). $R^{2}$ Given are figures for the fixed factors only.

\begin{tabular}{lrcrr}
\hline Fixed effects & Estimate & SE & \multicolumn{1}{c}{$t$} & \multicolumn{1}{c}{$p$} \\
\hline (Intercept) & 1.4237 & 0.5630 & 2.529 & 0.065 \\
Resource type & 0.3738 & 0.0772 & 4.845 & $<0.001$ \\
Location (upper/lower) & -0.5763 & 0.2436 & -2.365 & 0.077 \\
Resource type × Location & -0.2255 & 0.0772 & -2.922 & 0.004 \\
\hline
\end{tabular}

ants. The rather short exposure time of $75 \mathrm{~min}$ and our focusing on F. lemani nests is likely to have considerably reduced the probability of other species of ants in the alpine grassland environment discovering the baits. Therefore, our data only focuses on the foraging characteristics of $F$. lemani, which is the dominant species of ant in the area. This species has been shown to account for a major fraction of the predation and pollination (Dethier \& Cherix, 1982; Schiestl \& Glaser, 2012) attributed to ants in alpine grassland. Thus, at least to some extent our findings might reflect the overall effect of ants in this environment.

Using stable isotope analysis, O'Grady et al. (2010) confirm (in Ireland) that $F$. lemani is a generalist feeder, a character that it shares with most other species in alpine ant communities. Nevertheless, the number of visits to baits was surprisingly low and differed for the two types of baits and altitudes. Even when placed close to ant nests when the weather was predominantly warm, only a small fraction of the baits were visited by worker ants. The placement of the baits close to nests reduced the possible effect on the incidence of visits due to variable colony density (Kaspari et al., 2000).

We take the low incidence of visits as indicating a generally low activity density of foraging ants. This low foraging activity might indicate a low level of competition for food among ants in the alpine setting, although our study design did not target the intensity of competition. Further, the more severe thermal constraints at high altitudes (Bishop et al., 2006) might have delayed the onset of mass recruitment at the upper sites and resulted in the lower numbers of worker ants recorded at baits.

In addition, in the alpine grassland belt visits by ants to baits differed substantially between sites in the lower alpine belt and those just $70-180 \mathrm{~m}$ higher up. These small differences in altitude were associated with a reduction in the incidence visits from $63.75 \%$ to just $33.33 \%$, indicating that ant activity and thus possibly also competition for food clearly decreases as one approaches the upper altitudinal distribution of the ant. This was previously suggested by Dethier \& Cherix (1982) for ants in the Swiss Alps and later confirmed by Machac et al. (2011) in a study of alpine ant communities in the Alps and North America in which environmental filtering, instead of biotic interactions, was singled out as the predominant force structuring ant assemblages at high altitudes. Therefore, alpine ant communities appear not to be predominantly shaped by competition, but may be more strongly regulated by climatic constraints acting on colony foundation success or foraging behaviour (Cerdá et al., 2013). In line with these suggestions, ant colonies become increasingly sparsely distributed in the landscape at high altitudes and are mostly concentrated at micro-sites and in habitats that provide suitable conditions for establishing a colony (Seifert, 2007, 2017).

The clear preference for carbohydrate over protein is contrary to that predicted by our hypothesis. According to the compensation theory (Kaspari \& Yanoviak, 2001; Kaspari et al., 2012) ants should prefer the resource that is most limited. Our observations therefore indicate that car- 
bohydrates are in short supply for ants in the alpine grassland zone. Kaspari et al. (2012) show, for the tropics, that carbohydrates might be the more limited resource for ants that have rather carnivorous feeding habits. Hence, generalizing from our observations we conclude that in alpine habitats $F$. lemani ants are predominantly predacious and supplementing their diet with sufficient amounts of carbohydrates might be a limiting factor.

Recent work suggests that lipids could also be a limiting nutrient for carnivorous insects (Wilder et al., 2013). However, in our preliminary trials lipid resources (viz. peanut butter) simultaneously offered to the ants in alpine grassland was not visited; we therefore decided not to use this bait in the present study (Guariento E. \& Martini J., unpubl. results). Interestingly, exactly the opposite is reported by Peters et al. (2014) along an Afrotropical altitudinal gradient, in which they recorded an increase in the visits to lipid baits and reduction in visits to carbohydrate baits with increase in altitude.

A strong preference for carbohydrate at high altitudes is also reported by Spotti et al. (2015), who exposed baits in the Italian Alps over a whole vegetation period. This similar result supports the notion that our observations are not just due to the timing of surveys relative to the reproductive cycle of the colonies (Portha et al., 2002) or to seasonally variable resource supply and demand (Frizzi et al., 2016). Rather, it appears that a high demand for carbohydrates is a consistent characteristic, not just for F. lemani, but generally for alpine grassland ant communities. In our study, a significant preference for carbohydrates was only apparent if the numbers of foraging ants at the baits were taken into account. Indeed, we noticed the onset of food recruitment behaviour in F. lemani only at carbohydrate baits. The observation of many worker ants on flowers (Guariento E. \& Martini J., unpubl. observ.), where they sometimes even act as pollinators (Schiestl \& Glaser, 2012; Claessens \& Seifert, 2017), also supports the idea that carbohydrate is a limiting nutrient for ants in this harsh environment.

In Europe, extrafloral plant nectar and honeydew from phloem sucking Hemipteran insects are the major sources of carbohydrates for ants (Seifert, 2007). Both these sources might be in short supply at high altitudes in the Alps. For example, at high altitudes, plants that have extrafloral nectaries (EFN) reduce their investment in nectar production (Rasmann et al., 2014). Generally, EFN plants (Keeler, 1979; Koptur, 1985) as well as honeydew-producing insects (Stadler et al., 2001; Pellissier et al., 2012) tend to be scarcer at high altitudes. Hence, these mutualistic interspecific interactions that are essential for the supply of carbohydrate sources in lowlands appear to be less important and predictable in alpine environments.

Overall, the two fixed factors of our working hypotheses, viz. type of resource and altitudinal zone within the grassland belt, explained only small percentages (below 15\%) of the variance in the data sets, while the random factors accounted for larger percentages of variance in our data. One important source of variation is the size and actual nutrient status of the focal ant colonies, which it is not pos- sible to control in field experiments. Moreover, variation in ant colony densities are likely to reflect differences between sites as well the overall nutrient availability in the respective habitats. Further studies on trophic relationships of ants in alpine habitats, which are at the margins of the distribution for these otherwise dominant insects in many terrestrial ecosystems, will be needed to better understand the relative importance of abiotic and biotic factors in determining the altitudinal upper limit to ant occurrence.

ACKNOWLEDGEMENTS. We thank N. Kovacs and J. Paterno for great support in the field. We also thank S. Dullinger and K. Hülber for organizing the field trip and choosing the sampling locations. We are grateful to S. Vitecek for helpful advice on how to perform analyses in R. and N. Falk for a first proof reading of our manuscript. We finally thank five anonymous reviewers for suggestions that significantly improved the manuscript. This study was supported by travel grants from the Faculty of Life Sciences, University of Vienna.

\section{REFERENCES}

BARTON K. 2013: MuMIn: Multi-Model Inference. R Package Ver. 1.9. 13. The Comprehensive R Archive Network (CRAN), Vienna.

Bates D., Maechler M., Bolker B. \& Walker S. 2015: Fitting linear mixed-effects models using lme4. - J. Statist. Softw. 67: 1-48.

Bestelmeyer B.T., Agosti D., Alonso L.E., Brandao C.R., Brown W.J., Delabie J.H. \& Silvestre R. 2000: Field techniques for the study of ground-dwelling ants. In Agosti D., Majer J.D., Alonso L.E. \& Schultz T.R. (eds): Ants. Standard Methods for Measuring and Monitoring Biodiversity. Smithsonian Institution, Washington DC, pp. 122-144.

Bishop T.R., Robertson M.P., Rensburg B.J. \& Parr C.L. 2016: Coping with the cold: minimum temperatures and thermal tolerances dominate the ecology of mountain ants. - Ecol. Entomol. 42: 105-114.

Blüthgen N. \& FiedleR K. 2004: Preferences for sugars and amino acids and their conditionality in a diverse nectar-feeding ant community. - J. Anim. Ecol. 73: 155-166.

Blüthgen N., Gebauer G. \& Fiedler K. 2003: Disentangling a rainforest food web using stable isotopes: dietary diversity in a species-rich ant community. - Oecologia 137: 426-435.

Cerdá X., Arnan X. \& Retana J. 2013: Is competition a significant hallmark of ant (Hymenoptera: Formicidae) ecology. Myrmecol. News 18: 131-147.

Cherix D. \& Higashi S. 1979: Distribution verticale des fourmis dans le Jura vaudois et recensement préliminaire des bourdons. - Bull. Vaud. Sci. Nat. 74: 315-324.

Claessens J. \& Seifert B. 2017: Significant ant pollination in two orchid species in the Alps as adaptation to the climate of the alpine zone? - Tuexenia 37: 363-374.

Dethier M. \& Cherix D. 1982: Note sur les Formicidae du Parc national suisse. - Mitt. Schweiz. Entomol. Ges. 55: 125-138.

Dillon M.E. 2006: Into thin air: Physiology and evolution of alpine insects. - Integr. Compar. Biol. 46: 49-61.

Dunn R.R., Guénard B., Weiser M.D. \& SAnders N.J. 2010: Geographical gradients. In Lach L., Parr C.L. \& Abbott K.L. (eds): Ant Ecology. Oxford University Press, New York, pp. $38-58$.

Fiedler K., Kuhlmann F., Schlick-Steiner B.C., Steiner F.M. \& GeBAUER G. 2007: Stable N-isotope signatures of central European ants - assessing positions in a trophic gradient. - Insectes Soc. 54: 393-402. 
Fowler D., Lessard J.P. \& SANDERS N.J. 2014: Niche filtering rather than partitioning shapes the structure of temperate forest ant communities. - J. Anim. Ecol. 83: 943-952.

Frizzi F., Rispoli A., Chelazzi G. \& Santini G. 2016: Effect of water and resource availability on ant feeding preferences: a field experiment on the Mediterranean ant Crematogaster scutellaris. - Insectes Soc. 63: 565-574.

GLASER F. 2006: Biogeography, diversity and vertical distribution of ants (Hymenoptera: Formicidae) in Vorarlberg, Austria. Myrmecol. News 8: 263-270.

Grabherr G., Nagy L. \& Thompson D.B.A. 2003: An outline of Europe's alpine areas. In Nagy L., Grabherr G., Körner C. \& Thompson D.B. (eds): Alpine Biodiversity in Europe. Vol. 167. Springer Science \& Business Media, New York, 479 pp.

HoDKINSON I.D. 2005: Terrestrial insects along elevation gradients: species and community responses to altitude. - Biol. Rev. 80: 489-513.

HÖLldobler B. \& Wilson E.O. 1990: The Ants. Belknap Press of Harvard University Press, Cambridge, 732 pp.

KASPARI M. \& YANOVIAK S.P. 2001: Bait use in tropical litter and canopy ants - evidence of differences in nutrient limitation. Biotropica 33: 207-211.

Kaspari M., Alonso L. \& O’Donnellkwd S. 2000: Three energy variables predict ant abundance at a geographical scale. Proc. R. Soc. Lond. (B) 267: 485-489.

Kaspari M., Donoso D., Lucas J.A., Zumbusch T. \& Kay A.D. 2012: Using nutritional ecology to predict community structure: a field test in Neotropical ants. - Ecosphere 3(11):93, $15 \mathrm{pp}$.

KAY A. 2004: The relative availabilities of complementary resources affect the feeding preferences of ant colonies. Behav. Ecol. 15: 63-70.

KeELER K.H. 1979: Distribution of plants with extrofloral nectaries and ants at two elevations in Jamaica. - Biotropica $152-154$.

KoptuR S. 1985: Alternative defenses against herbivores in Inga (Fabaceae: Mimosoideae) over an elevational gradient. Ecology 66: 1639-1650.

Lach L., Parr C. \& Abbott K. (eds) 2010: Ant Ecology. Oxford University Press, New York, 402 pp.

Machac A., Janda M., Dunn R.R. \& Sanders N.J. 2011: Elevational gradients in phylogenetic structure of ant communities reveal the interplay of biotic and abiotic constraints on diversity. - Ecography 34: 364-371.

Nagy L. \& Grabherr G. 2009: The Biology of Alpine Habitats. Oxford University Press, New York, $376 \mathrm{pp}$.

O'Grady A., Schmidt O. \& Breen J. 2010: Trophic relationships of grassland ants based on stable isotopes. - Pedobiologia 53: 221-225.

Orivel J., Klimes P., Novotny V. \& Leponce M. 2018: Resource use and food preferences in understory ant communities along a complete elevational gradient in Papua New Guinea. - Biotropica [in press].

Pellissier L., Litsios G., Fiedler K., Pottier J., Dubuis A., PraDeRVAnd J.N., Salamin N. \& Guisan A. 2012: Loss of interactions with ants under cold climate in a regional myrmecophilous butterfly fauna. - J. Biogeogr. 39: 1782-1790.

Peters M.K., Mayr A., Röder J., Sanders N.J. \& SteffanDEWENTER I. 2014: Variation in nutrient use in ant assemblages along an extensive elevational gradient on Mt. Kilimanjaro. J. Biogeogr. 41: 2245-2255.
Portha S., Deneubourg J.L. \& Detrain C. 2002: Self-organized asymmetries in ant foraging: a functional response to food type and colony needs. - Behav. Ecol. 13: 776-781.

Rasmann S., Buri A., Gallot-Lavallée M., Joaquim J., Purcell J. \& Pellissier L. 2014: Differential allocation and deployment of direct and indirect defences by Vicia sepium along elevation gradients. - J. Ecol. 102: 930-938.

R Core Team 2017: R: A Language and Environment for Statistical Computing. R Foundation for Statistical Computing, Vienna. URL: https://www.R-project.org/.

Reymond A., Purcell J., Cherix D., Guisan A. \& Pellissier L. 2013: Functional diversity decreases with temperature in high elevation ant fauna. - Ecol. Entomol. 38: 364-373.

SCHIESTL F.P. \& Glaser F. 2012: Specific ant-pollination in an alpine orchid and the role of floral scent in attracting pollinating ants. - Alpine Bot. 122: 1-9.

SeIFert B. 2007: Die Ameisen Mittel- und Nordeuropas. Tauer: Lutra Verlags- und Vertriebsgesellschaft, Görlitz, 368 pp.

SeIFERT B. 2017: The ecology of Central European non-arboreal ants -37 years of a broad-spectrum analysis under permanent taxonomic control. - Soil Organisms 89: 1-67.

Spotti F.A., Castracani C., Grasso D.A. \& Mori A. 2015: Daily activity patterns and food preferences in an alpine ant community. - Ethol. Ecol. Evol. 27: 306-324.

Stadler B., Fiedler K., Kawecki T.J. \& Weisser W.W. 2001: Costs and benefits for phytophagous myrmecophiles: when ants are not always available. - Oikos 92: 467-478.

Stuble K.L., Rodriguez-Cabal M.A., McCormick G.L., Jurić I., DuNN R.R. \& SANDERS N.J. 2013: Tradeoffs, competition, and coexistence in eastern deciduous forest ant communities. Oecologia 171: 981-992.

SzewCZYK T. \& MCCAIN C.M. 2016: A systematic review of global drivers of ant elevational diversity. — PLOS ONE 11(5): e0155404, 18 pp.

Tiede Y., Schlautmann J., Donoso D.A., Wallis C.I.B., Bendix J., BRANDL R. \& FarWig N. 2017: Ants as indicators of environmental change and ecosystem processes. - Ecol. Indicat. 83: $527-537$.

TSCHINKEL W.R. 2002: The natural history of the arboreal ant, Crematogaster ashmeadi. - J. Insect Sci. 2: 2-15.

VÉLE A. \& ModLInger R. 2016: Foraging strategy and food preference of Formica polyctena ants in different habitats and possibilities for their use in forest protection. - For. J. 62: 223-228.

WagNer H.C. 2014: Die Ameisen Kärntens. Verbreitung, Biologie, Ökologie und Gefährdung. Naturwissenschaftlicher Verein für Kärnten, Klagenfurt, 464 pp.

Wetterer J.K., Miller S.E., Wheeler D.E., Olson C.A., Polhemus D.A., Pitts M., Ashton I.W., Himler A.G., Yospin M.M., Helms K.R. et AL. 1999: Ecological dominance by Paratrechina longicornis (Hymenoptera: Formicidae), an invasive tramp ant, in biosphere 2. - Fla Entomol. 82: 381-388.

Wicкнам H. 2009: ggplot2: Elegant Graphics for Data Analysis. Springer, Houston, TX, 260 pp.

Wilder S.M., Norris M., Lee R.W., Raubenheimer D. \& Simpson S.J. 2013: Arthropod food webs become increasingly lipid-limited at higher trophic levels. - Ecol. Lett. 16: 895-902.

Received November 7, 2017; revised and accepted April 10, 2018 Published online May 9, 2018 